\title{
ACRL Award Winners, 1991
}

\author{
By Carolyn DeBonnett
}

ACRL Program Officer for Membership

\section{Join us in honoring these outstanding individuals.}

$\mathbf{T}$

he Association of College and Research

Libraries is pleased to announce the recipients of the 1991 awards. These winners were selected by separate award juries and will be honored at the ALA Annual Conference in Atlanta. Dates and times for the presentations are noted for each award.

The deadline for most of the 1992 awards is December I, 1991. Information about nominations and applications for the 1992 awards is available from Carolyn DeBonnett, Program Officer, ACRL/ALA, 50 East Huron St., Chicago, IL 60611; (800) 545-2433 ext. 2510, or (312) 280 2510 .

\section{Academic or Research Librarian of the Year Award}

Rrchard De Gennaro, the Roy E. Larsen Librarian of Harvard College, is the recipient of the ACRL's \$3,000 Academic or Research Librarian of the Year Award. De Gennaro will receive the award immediately following the ACRL President's Program at 4:30 p.m. on Monday, July 1 , at a reception in his honor during the ALA Annual Conference in Atlanta. Baker \& Taylor Books donates the cash award and citation.

The award is given annually to recognize an individual who is making an outstanding contribution to academic or research librarianship and library development.

"In his career as an academic librarian, De Gennaro has been an outstanding administrator, a thoughtful and perceptive writer, a mentor to other librarians, and a leader in professional associations, including ACRL, Association of Research Libraries (ARL), and the Library and Information Technology Association (LITA)," said Edward G. Holley, chair of the Academic or Research Librarian of the Year Award Committee.

"As one colleague has described him, 'His written and spoken reflections on the past and visions for the future are the contributions of a library statesman,' and he truly deserves recognition as Academic or Research Librarian of the Year."

"A man for all seasons," begins the cita-

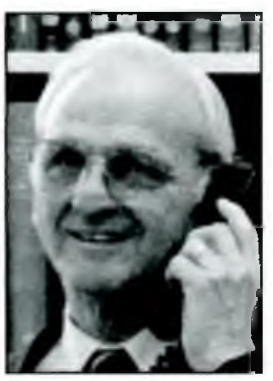

Richard DeGennaro tion for the award, "his leadership of three major research libraries, of two professional associations, and of numerous committees and boards, has resulted in major advances in changing the shape of library management and the integration of technology into library operations, areas in which he is recognized nationally and internationally as an authority.

"Even more importantly, De Gennaro's skill as a writer, speaker, and teacher has influenced not only his peers but also a new generation of librarians. As a colleague has noted, 'his thoughtful observations and questions have refreshed the profession by their cogency, their ability to penetrate below the surface, and their relevance to major issues and trends in academic and research librarianship.' In a time when there was uncertainty and 
resistance to the new technological world, De Gennaro's papers and articles made the profession look at libraries in a different way; he also helped us understand that we must be prepared for the future. He writes for librarians at all levels in all types of libraries"

De Gennaro began his career at Harvard, holding positions of increasing administrative responsibility. De Gennaro previously served as director of libraries at the University of Pennsylvania and director of the New York Public Library.

His articles on library management and technology in Library Journal and American Libraries were among the most influential published during the 1970 's and 1980's. These and other articles have been collected into a book, Libraries, Technology and the Information Marketplace: Selected Papers, G.K. Hall, 1987.

De Gennaro is a recipient of the Melvil Dewey Medal (1986), and received the Distinguished Alumni Award for the School of the Library Service at Columbia, the R.R. Bowker Memorial Lecture Award (1979), and the Samuel Lazerow Memorial Lecturer Award (1983).

\section{Hugh C. Atkinson Memorial Award}

Donald E. Rigcs, dean of the University Library and Professor of Information and Library Studies at the University of Michigan, is the recipient of the Hugh C. At-

kinson Memorial Award. Riggs will receive this award, which carries a cash prize of $\$ 2,000$ and a citation, during the 1991 ALA Annual Conference in Atlanta, at the ALCTS membership meeting, Monday, July 1 , at 7:30 a.m.

"Don Riggs has provided exemplary leadership in all areas recog-

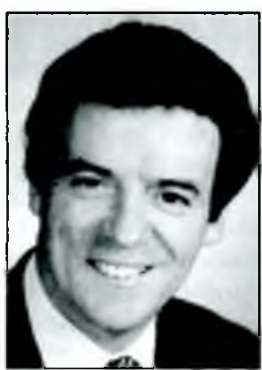

Donald E. Riggs nized by the Atkinson Award," said Judith N. Kharbas, chair, Hugh C. Atkinson Mem-orial Award Committee. "He has, in all his positions, taken risks which have led to major improvements in library organization, collections, and services. Don Riggs is dedicated to promoting the value of excellent library service. $\mathrm{He}$ is one of the profession's outstanding leaders and achievers."

The award, established to honor the life and accomplishments of Hugh C. Atkinson, one of the major innovators in modern librarianship, recognizes outstanding accomplishments (including risk taking) by academic librarians related to library automation or library management.

While dean of University Libraries, Arizona State University (1979-90), Riggs accomplishments included increasing the size of the collection, implementing an online public access catalog, overseeing several new library building projects, and raising funds.

The author of eight books, Riggs has extensive writing and editing experience. He is presidentelect of the OCLC Users Council and has held numerous leadership positions in professional organizations.

The Hugh C. Atkinson Memorial Award is jointly sponsored by the Association of College and Research Libraries (ACRL), Association for Library Collections and Technical Services (ALCTS), the Library Administration and Management Association (LAMA), and the Library and Information Technology Association (LITA), four divisions of the American Library Association. The award is funded by an endowment created by division, individual, and vendor contributions given in memory of Hugh C. Atkinson.

\section{Doctoral Dissertation Fellowship}

Kamala Balaramav, candidate at the University of Hawaii, Interdisciplinary Doctoral Program in Communications and Information Science, has been chosen to received the Doctoral Dissertation Fellowship. The award, $\$ 1,000$ and a plaque, is donated by the Institute for Scientific Information and will be presented at the ACRL President's Program in Atlanta, Monday, July 1 , which begins at 2:00 p.m.

Balaraman's proposed dissertation is entitled, "Study of Individ-

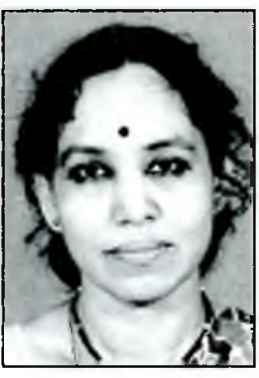

Kamala Balaraman ual Differences in the Use of CD-ROM Databases by Undergraduate Students at the University of Hawaii." According to Roger Durbin, chair of the award jury, "Ms. Balaraman's proposal to study users of CD-ROMs is an important contribution to academic librarianship. Her focus on computer affinity versus computer literacy for use in determining user interfaces may provide new insights into computer datafile searching and into methods of bibliographic instruction. Ms. Balaraman's research will advance research into ways of creating environments conducive to the undergraduate academic process."

Her professional career includes many years of service as a subject specialist and information sci- 
entist with the International Nuclear Information System Group in Bombay, India.

The fellowship is presented annually to a doctoral student in the field of academic librarianship whose research indicates originality, creativity, and interest in scholarship.

\section{K. G. Saur for Best $C \mathfrak{G R L}$ Article}

"The Electronic Revolution in Libraries: Microfilm Deja Vu?," an article by susan A. Cady appearing in the July, 1990, issue of College and Research Libraries has been named the winner of the K.G. Saur Award for Best College and Research Libraries Article. Cady will receive a $\$ 500$ award and a plaque, donated by publishing company, K.G. Saur, that will be presented at the ACRL President's Program in Atlanta, Monday, July 1 , which begins at 2:00 p.m.

Dan T. Bedsole, li-

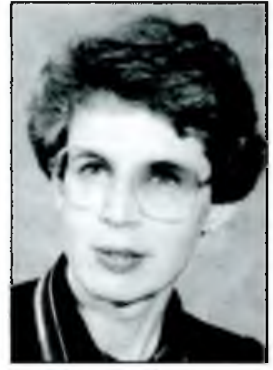

Susan A. Cady brary director of Randolph-Macon College, and the chair of the award jury said, "Sketching the interesting history of microfilming and the use of microfilm in libraries, the author draws parallels to the growing use of electronic technologies today. The factors likely to determine the extent to which electronic full-text products will eventually replace microfilm and/or hard copy are considered. The history of microfilm sheds light on how librarians can "avoid costly errors by learning the limitations of the technology and planning for a multiplicity of modes of access and formats."

Susan Cady is associate director of technical services at Lehigh University. She is active in a number of associations.

The K.G. Saur Award was established to recognize the most outstanding article published in College and Research Libraries during the preceding volume year. The winning article is selected on the basis of originality, timeliness, relevance to ACRL areas of interest, and concern and quality of writing.

\section{Miriam Dudley Bibliographic Instruction Librarian of the Year Award}

Carla Stoffle, deputy director of the University Library at the University of Michigan, has been named the Miriam Dudley Bibliographic Instruction Librarian of the Year. The award, $\$ 1,000$ and a plaque, is donated by Mountainside Publishing,
Ann Arbor, on behalf of its publication, Research Strategies, and is administered by the ACRL Bibliographic Instruction Section (BIS). Stoffle will receive the award during the ALA Annual Conference in Atlanta at the BIS program on Sunday, June 30 , at 2:00 p.m.

"Carla Stoffle's sustained and substantive contributions have influenced the direction and shape of bibliographic instruction in academic institutions across the country," said Cerise Oberman, chair of the

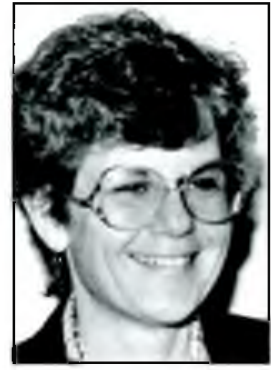

Carla Stoffle ACRL Miriam Dudley Bibliographic Instruction Award Committee. "Carla Stoffle embodies the spirit of the Miriam Dudley Award - a spirit of creativity, leadership, and commitment."

Stoffle has been a leader in user education throughout her various positions at the University of Wisconsin-Parkside, Eastern Kentucky University, and the University of Kentucky. Her current position includes responsibility for the design and implementation of technological and service innovation in support of the intellectual life of the university. Stoffle, a past president of ACRL, currently serves as treasurer and member of the executive board (1988-92) of the ALA.

She is the author of three books, several articles, chapters, and papers, and has participated in several panels and workshops. Stoffle was awarded the Reference Service Press Award (1986) as co-author of the most outstanding article in $R Q$ and was named Outstanding Alumnus of the College of Information Science, University of Kentucky (1989).

The Dudley Award was established to recognize librarians who have made an especially significant contribution to the advancement of bibliographic instruction.

\section{Community College Learning Resources Achievement Awards}

Jimme Anne Nourse and Rudy Widman, of Fort Pierce, Florida, are the recipients of the CJCLS Community College Learning Resources Achievement Award for Program Development.

"Dr. Widman and Ms. Rouse were chosen for this year's award in recognition of the excellent work they have done on developing their course, "Electronic Access to Information," as well as for the degree in which their work has integrated the Indian Rivers Learning Resources program into the academic program of the college," said W. Lee 
And when it comes to indexing conference proceedings, no other sources rival the current, multidisciplinary coverage offered by the Index to Scientific \& Technical Proceedings ${ }^{\text {th }}$ and the Index to Social Sciences \& Humanities Proceedings ${ }^{*}$.

Because they index at the paper level, these reference volumes tell you what research papers have been presented at conferences around the world - in hundreds of key disciplines-long before

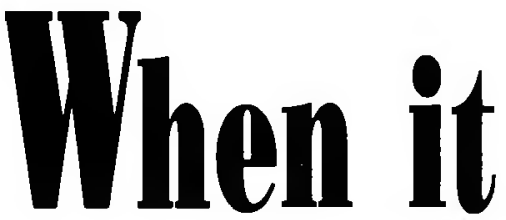
they appear in journals or other indexes. Much of it is breakthrough work. And all of it is too important to wait months to know about.
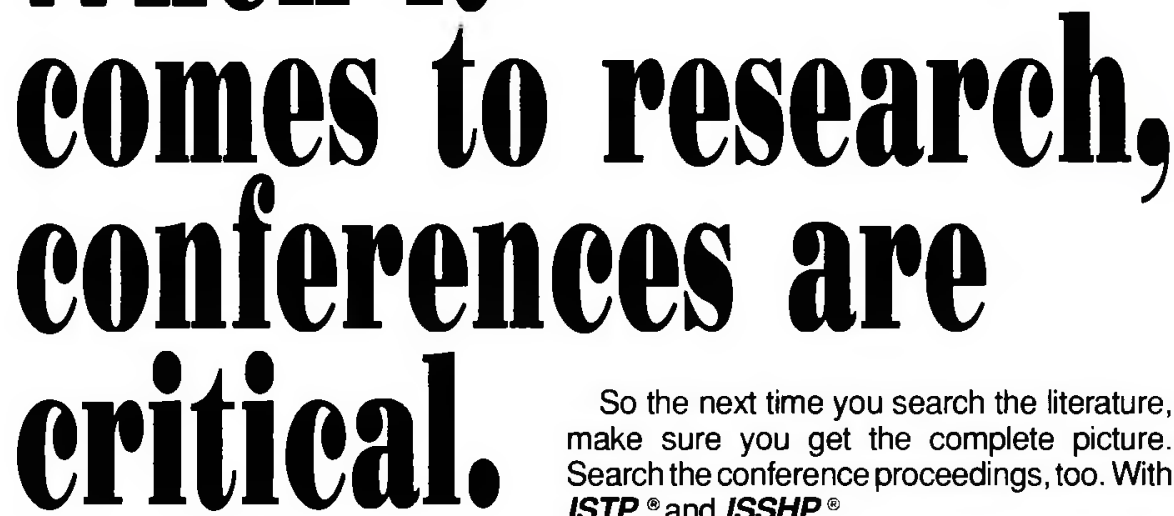

So the next time you search the literature, make sure you get the complete picture. Search the conference proceedings, too. With ISTP ${ }^{\circledR}$ and ISSHP ${ }^{\circledR}$.

To subscribe - or to receive a free sample issue - call toll-free at 800-336-4474, operator R401, or write the ISI office nearest you.

1991 ISTP

12 issues plus annual cumulation $\ldots \ldots \ldots . \$ \$ 1,225$ 1991 ISSHP

3 quarterly issues p/us annual cumulation ... \$ $\$ 825$

Institute for Scientific Information

3501 Market Street, Philadelphia, PA 19104 Europe: 132 High Street, Uxbridge, Middlesex, UB8 1DP, U.K. 


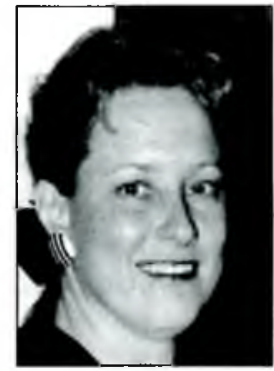

Jimmie Anne Nourse

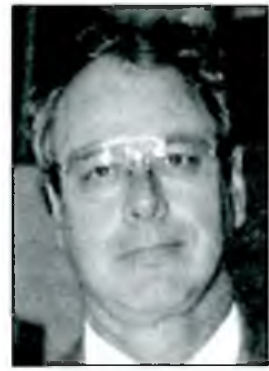

$R u d y$ Widman
Hisle, chair of the ACRL Community and Junior College Libraries Section.

"Combined with course objectives of helping students develop sophisticated search strategies to locate information resources for classroom assignments, this course helps make the Indian River Community College Learning Resources program an integral part of the college's academic program," he said. The course introduces students to electronic information retrieval systems, including NewsBank, Grolier's Electronic Encyclopedia, ERIC, and Medline.

Widman is director of learning resources at the Indian River Community College.

Nourse is head of library services at Indian River Community College.

Widman and Nourse, authors of five joint publications, will receive their award at the ALA Annual Conference in Atlanta during the CJCLS Conference program on June 29, at 8:30 a.m.

James O. Wallace, retired director of Learning Resources at San Antonio College, is the recipient of the CJCLS Community College Learning Resources Achievement Award for Leadership.

The award is for Wallace's lifetime dedication to the library profession and to the improvement of learning resources programs in community colleges.

"J.O. Wallace is a giant among community college learning resources professionals," said W. Lee Hisle, chair of the ACRL Commu-

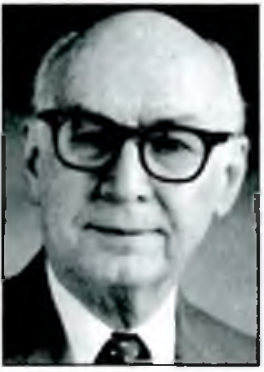

James $O$. Wallace nity and Junior College Libraries Section. "He was selected for the award not only for his contributions to the profession over the past 40 years, but for his recent work as co-chair of the ACRL/Association for Educational Commu- nications and Technology (AECT) Joint Committee, which revised the "Standards for Community, Junior, and Technical College Learning Resources Programs."

"This multi-year effort was the first substantive revision for over 10 year " Hisle said. "His skills at building collaborative lationships were often tested during the revision, rocess. The depth of his experience and the level of his professionalism are qualities to which all LRS professionals should aspire."

President of the Friends of the San Antonio Public Library, Wallace also serves as volunteer library director at the Hispanic Baptist Theological Seminary in San Antonio.

The 1969 Texas Librarian of the Year, Wallace received the ACRLALA Distinguished Service Award in 1989. Wallace has had numerous articles published, served on a variety of federal and state grants advisory committees, and has been active in professional organizations.

He will receive his award at the ALA Annual Conference in Atlanta during the CJCLS Conference Program on Saturday, June 29, at 8:30 a.m.

\section{Katharine Kyes Leab and Daniel J. Leab American Book Prices Current Exhibition Catalogue Awards}

The Katherine Kyes Leab and Daniel J. Leab American Book Prices Current Awards have been announced by the Rare Books and Manuscripts Section (RBMS) of ACRL. The awards are for the three best catalogues published by American or Canadian institutions in conjunction with exhibitions of books and/or manuscripts.

First place winners in three divisions (based on expensive, moderate, and inexpensive production cost) and institutions submitting catalogues are as follows: "Stephen Harvard: A Life in Letters," submitted by the Hougrton Lirrary, Harvard University (Division I); "The Face of the Moon: Galileo to Apollo," entered by the LinDa HaLL LIBrary, Kansas City, Missouri. (Division II); and "Fifteenth Century Italian Woodcuts from the Biblioteca Classense, Revenna," submitted by the Thomas Fisher Rare Book Library, University of Toronto (Division III).

“' 'Stephen Harvard: A Life in Letters' exhibits impeccable design and beautiful color printing, the whole comprising a fitting tribute to the work of an extraordinary man," said Pat Bozeman, chair of the Exhibition Catalogue Awards Committee.

"The Face of the Moon: Galileo to Apollo," was written for an exhibition at the Linda Hall Library. "The catalogue documents a brilliantly conceived exhibition that included lunar maps from Galileo's Sidereus nuncius (1610) to photographs taken from the Apollo 17 spacecraft, published in 1978," 


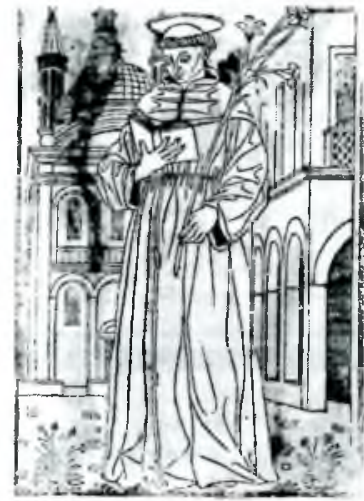

\section{Fifteenth Century}

Italian Woodcuts

from the Biblioteca Classense, Ravenna

Thomas Fisher Rare Book Library, University of Toronto, Fifteenth Century Italian Woodcuts

said Bozeman. "It is most noteworthy for the careful and tasteful integration of informative subject and exemplary design - a tour de force of black ink on white paper that never overshadows the catalogue's content."

"The Division III award is well earned by the scholarly, readable and useful, as well as pleasantly designed 'Fifteenth Century Italian Woodcuts from Biblioteca Classense, Ravenna," she said. "Its black and white illustrations highlight unusual items not easily accessible to students in North America and, as such, will be very useful in the history of the book."

In addition to the first place winners, four catalogues were singled out for honorable mention: in Division I, "Encyclopedism from Pliny to Borges" from the University of Chicago's Special ColLEctions; in Division II, "Thomas Merton: The Poet and the Contemplative Life," entered by the Rare Book and Manuscript Library in the Butler Library, Columbia UNIVERSITY, and NonThwestERN UNIVERSITY LibranY's "Why Is This Night Different? Passover Haggadot from the Stephen P. Durchslag Collection"; and in Division III, "On the Edge of the War Zone: Women Writers and World War I," submitted by McFarlin Library's Department of Special Collections at the UNIVERSITY OF TULSA.

Criteria for granting awards include excellence in originality, informational content, visual impact

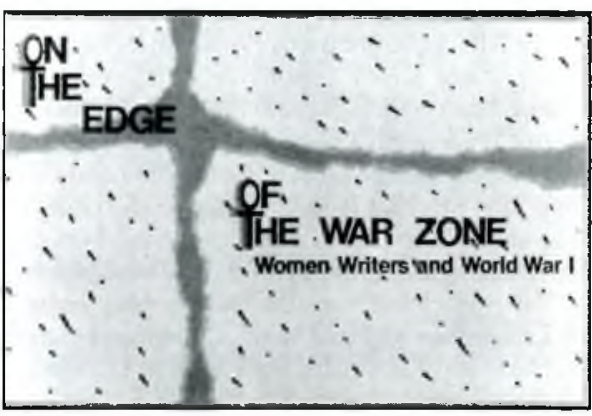

Special Collections, University of Tulsa, McFarlin Library, On the Edge of the War Zone

and appropriateness of design, as well as success with intended audience and accuracy of detail.

Catalogues published between September 1, 1989 and August 31, 1990, were eligible for the 1991 competition. Entries for September 1, 1990, through August 31, 1991 must be submitted by for judging by September 30, 1991.

Special recognition will be given to each of this year's seven winners at the RBMS Exhibition Catalogue Awards Program on Sunday, June 30 at the ALA Annual Conference in Atlanta.

For further information, printed guidelines, and entry forms contact Pat Bozeman, chair, RBMS Exhibition Catalogue Awards Committee, c/o Special Collections, University of Houston Libraries, Houston, TX 77204-2091. Telephone: (713) 749-2726 or fax (713) 749-3867.

\section{Martinus Nijhoff International: West European Specialist Study Grant}

Nancy S. Reinhardt, rare books cataloger/bibliographer at Harvard University, has been selected to receive the 1991 Martinus Nijhoff International West European Specialist Study Grant. The grant covers air travel to and from Europe, transportation in Europe, and lodging and board for fourteen consecutive days. Reinhardt will receive her award at the ALA Annual Conference in Atlanta during the WESS annual program and membership meeting on Monday, July 1 , at $8: 30$

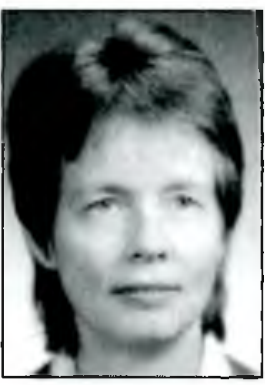

Nancy S. Reinhardt a.m.

"The winning proposal represents an original and fascinating piece of research which intersects bookselling history with collection development 
and curriculum reform," said Martha Brogan, chair of the Nijhoff International West European Specialist Study Grant committee, "Moreover, it makes more widely known the contributions to Henry Wadsworth Longfellow as a book selector for Harvard College Library. Committee members found the proposal to be imaginative and compelling, and believe that it illustrates the link between librarianship and the wider scholarly community."

The project will trace the book-buying journey of Longfellow to Stockholm, Copenhagen, Amsterdam, and Rotterdam from April to December 1835 attempting to establish the date and place of his purchase, the names of the book dealers, and the list of titles acquired. While in the Netherlands, Reinhardt will try to reconstruct the content of a shipment of Dutch books lost at sea.

Reinhardt received her Ph.D. in comparative and dramatic literature from Cornell University and her MLS from Simmons College. She has held several positions at Harvard University, and one at the University of California-Santa Barbara.

The grant is awarded to an ALA member to study some aspect of West European studies, librarianship, or the book trade.

\section{ACRL national conference moves to}

\section{Salt Lake City}

\section{Julian Bond and Paul Saffo to speak at ACRL's 6th National Conference, April 12-14, 1992}

$\mathbf{A}$ new site and dates for the ACRL Sixth National Conference was approved on March 11, 1991, by the American Library Association Executive Board. The conference will be held April 12-14, 1992, in Salt Lake City Utah.

The conference was originally planned for April 1-4, 1992 in Phoenix, Arizona. The ACRL Board of Directors voted January 13, 1991, to move the conference out of Phoenix because of the failure of the Arizona referendum to establish a paid state holiday in honor of the late Dr. Martin Luther King, Jr.

Richard M. Dougherty, president of the American Library Association commended the ACRL Board for acting on their convictions and said he particularly appreciated the quick action and commitment of the chapter representatives, ALA's chapter relations staff, and ACRL officers and staff. "It was not an easy task to work out a mutually satisfactory solution to this very complex and sensitive issue," Dougherty said. "All involved are to be congratulated."

ACRL had considered meeting in St. Louis, Missouri, March 25-28, 1992, but learned that a St. Louis conference would conflict with state association meetings in Illinois and Kansas. Salt Lake City was able to move a local meeting out of its center to allow space for ACRL.

The request to hold the conference in Utah was accompanied by letters of welcome from the Utah Library Association and all contiguous state library associations.

"The Utah Library Association is happy to welcome the ACRL conference to Salt Lake," said Eileen Longsworth, president of the Utah Library Association and director of the Salt Lake County Public Library System. "We look forward to the opportunity of showing off our beautiful state and meeting with our colleagues from around the country."

Joseph A. Boissé, ACRL national conference chair and director of the University of California, Santa Barbara Library, stated he was pleased that the new site is set and the Conference Committee can continue planning. Boissé said the committee has selected former Georgia state representative and civil rights activist Julian Bond and futurist Paul Saffo to speak at the conference. The conference theme is "Academic Libraries Achieving Excellence in Higher Education."

Preconference workshops will be held on Saturday, April 11, 1992, and the all-conference reception that evening. Conference programs will begin at 9:00 a.m. on Sunday, April 12 and end at 4:00 